\title{
EFEKTIVITAS PENGELOLAAN ZAKAT DI BAZDA KOTA BLITAR DITINJAU DARI UU NOMOR 38 TAHUN 1999
}

\author{
Abdul Kadir \\ Fakultas Syari'ah UIN Maliki Malang \\ E-mail : masdoel_bajoe@yahoo.co.id
}

\begin{abstract}
The teaching of alms is a comprehensive ritual for social responsibility. In Indonesia, the discussion about Islamic economy leads to the discussion of alms and its implementation. The law base of alms is UU no 38/1999. Bazda kota Blitar is one center of alms collection in East Java. The collected data shows that the management of Bazda cannot work effectively as expected. There are at least three main problems: limitation of facility, lack of professional human resources, and lack of political will. Ajaran sedekah adalah ritual komprehensif untuk tanggung jawab sosial. Di Indonesia, diskusi tentang ekonomi Islam mengarah pada diskusi tentang zakat dan pelaksanaannya. Dasar hukum zakat adalah UU no 38/1999. Bazda kota Blitar adalah salah satu pusat pengumpulan zakat di Jawa Timur. Data yang dikumpulkan menunjukkan bahwa pengelolaan Bazda tidak bisa bekerja secara efektif seperti yang diharapkan. Setidaknya ada tiga masalah utama: keterbatasan fasilitas, kurangnya sumber daya manusia yang profesional, dan kurangnya kemauan politik.
\end{abstract}

Keywords : efektivitas, Management Zakat, UU No. 38/1999

Sebagai salah satu pilar Islam, zakat adalah fardlu 'ain dan kewajiban ta'abbudi. Ia juga merupakan ibadah maliyah ijtimai'iyah (ibadah yang berkaitan dengan ekonomi dan kemasyarakatan) yang mempunyai status dan peran penting dalam syari'at Islam. Bahkan al-Qur'an menjadikan zakat dan shalat sebagai lambang dari keseluruhan ajaran Islam. ${ }^{118}$ Zakat adalah suatu ibadah maliyah yang lebih menjurus kepada aspek sosial, untuk mengatur kehidupan manusia dalam hubungannya dengan Allah, dan dalam hubungannya dengan sesama manusia. Kalau shalat lebih menjurus kepada pembinaan kepribadian yang mulia, maka zakat lebih menjurus kepada pembinaan kesejahteraan masyarakat ${ }^{119}$. Oleh sebab itu tidak heran, jika ibadah zakat ini juga merupakan ibadah bagi umat-umat sebelum Islam, sebagaimana yang telah diterangkan Allah di dalam al-Qur'an. ${ }^{120}$

Di Indonesia, berbicara tentang ekonomi Islam, akan mengarah kepada pelaksanaan zakat. Di sini, lembaga zakat yang pada umumya dipersepsikan sebagai lembaga keagamaan, diusahakan untuk ditransformasikan menjadi lembaga sosial-ekonomi. Zakat selalu dikemukakan sebagai suatu konsep $p a-$

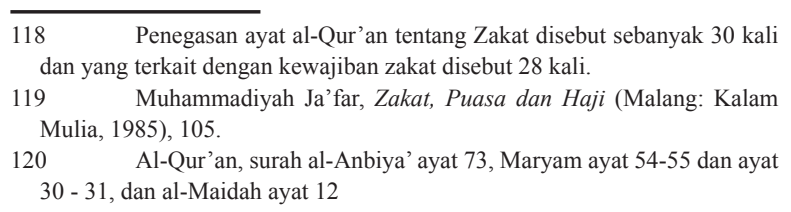

nacea (obat mujarab) untuk memberantas kemiskinan. Padahal dalam peraktek zakat dilakukan sekedar untuk memenuhi rukun Islam yang ketiga dan karena itu lebih banyak merupakan masalah pribadi. Dampaknya tidak lebih sekedar meringankan beban konsumsi seseorang untuk beberapa hari saja. Dengan kata lain, dampak sosial-ekonomi pelaksanaan zakat belum nampak, kecuali untuk beberapa kasus, dimana zakat telah diarahkan sebagai suatu program sosial, tapi ini baru dilakukan dalam skala kecil.

Kota Blitar memiliki potensi zakat yang tidak kecil, ini biasa dilihat dari penduduk Kota Blitar yang beragama Islam (berdasarkan data keagamaan tahun 2004 sebesar \pm 356.376 jiwa). ${ }^{121}$ Potensi besar seperti ini, tampaknya belum bisa ditangkap secara baik oleh lembaga-lembaga sosial keagamaan khususnya yang bergerak dalam bidang pengelolaan zakat dimana selama ini pengelolaan zakat masih banyak dilakukan secara tradisional baik dalam pengumpulan maupun pendistribusian. Padahal jika potensi umat itu dapat dikelola dengan baik tentu akan sangat membantu dalam pembangunan sosial, khususnya di bidang ekonomi umat Islam. Hal ini juga setelah mengamati kontak langsung dengan pengurus BAZDA Kota Blitar, sumber dana zakat hanya didapat dari zakat profesi, infaq dan shodaqah, walaupun pengurus BAZDAKota Blitar sendiri lebih banyak bermukim di masyarakat

\footnotetext{
$121 \quad$ Data diperoleh dari Kantor Badan Pusat Statistik Kota Blitar pada

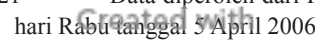


daripada di instansi pemerintah, termasuk ketuanya sendiri dan para pengawas.

Karena belum ada lembaga yang profesional seperti itu, maka berdasarkan hasil pengamatan sepintas, terkesan banyak masyarakat Islam (wajib zakat) Kota Blitar masih enggan untuk berpartisipasi di lembagalembaga pengelolaan zakat yang ada, sehingga belum memenuhi sasaran yang diharapkan. Ada semacam kekhawatiran di kalangan wajib zakat (muzakki), kalau-kalau zakat itu tidak akan sampai ke tangan penerima zakat (mustahiq) yang sebenarnya berhak. Ditambah lagi dengan sistem administrasi BAZDA Kota Blitar yang kurang permanen dan sehingga terkesan pengurus/pejabat yang mendapatkan Surat Keputusan Wali Kota Blitar aktif pada saat menjelang lebaran idul fitri.

Di Indonesia, pengelolaan zakat diatur berdasarkan Undang-Undang No. 38 Tahun 1999 dengan Keputusan Menteri Agama (KMA) No. 581 Tahun 1999 tentang pelaksanaan Undang-Undang tentang Pengelolaan Zakat. Bukankah Dalam Bab III UU No. 38 Tahun 1999 dikemukakan bahwa organisasi pengelola zakat terdiri atas dua jenis, yaitu Badan Amil Zakat (pasal 6) dan Lembaga Amil Zakat (pasal 7). Selanjutnya pada bab tentang sanksi (Bab VIII) dikemukakan pula bahwa setiap pengelola zakat yang karena kelalaiannya tidak mencatat atau mencatat dengan tidak benar tentang zakat, infaq, shadaqah, sebagaimana yang dimaksud dalam pasal 8 , pasal 12 dan pasal 11 UU No. 38 Tahun 1999, diancam dengan hukuman kurungan selama-lamanya tiga bulan dan/ atau denda sebanyak-banyaknya Rp. 30.000.000,(tiga puluh juta rupiah). Sanksi ini tentu dimaksudkan agar BAZ dan LAZ yang ada di negara kita menjadi pengelola zakat yang kuat, amanah dan profesional dan dipercayai masyarakat, sehingga pada akhirnya masyarakat secara sadar dan sengaja akan menyerahkan zakatnya kepada lembaga pengelola zakat.

Itulah sebabnya, peneliti sangat menaruh perhatian untuk melihat secara dekat kinerja BAZDA kota Blitar dalam melaksanakan program pengelolaan dana ZIS. Fokus perhatian dalam penelitian ini akan dikhususkan pada persoalan bagaimana manajemen pengelolaan, pendayagunaan dan faktor penghambat pengelolaan zakat oleh BAZDA kota Blitar sebagai suatu lembaga penghimpun maupun penyalur dana ZIS kepada masyarakat (umat).

Dana ZIS yang dimaksud pada pembahasan ini adalah dana zakat, infaq dan bentuk shadaqah serta amalan ibadah yang berbentuk harta kekayaan lainnya. Karena wilayah kerja BAZDA kota Blitar berkaitan

dengan macam-macam sumber dana tersebut. Hal ini sesuai dengan aturan perundang-undangan yang berlaku, sebagaimana diatur dalam Keputusan Menteri Agama RI. Nomor 581 Tahun 1999 tentang Pelaksanaan Undang Undang Nomor 38 Tahun 1999 tentang Pengelolaan Zakat, yaitu pasal 27 yang berbunyi, bahwa lingkup kewenangan pengumpulan zakat sebagaimana dimaksud pada pasal 25 termasuk harta selain zakat seperti infaq, hibah, wasiat, waris dan kafarat.

\section{METODE PENELITIAN}

Peneliti menggunakan penelitian kualitatif dengan pendekatan kualitatif deskriptif. Penelitian kualitatif digunakan apabila data-data yang dibutuhkan berupa sebaran-sebaran informasi yang tidak perlu dikuantifikasi. ${ }^{122}$ Penelitian ini bisa juga dengan menggunakan pendekatan sosiologis atau empiris. ${ }^{123}$

Untuk memperoleh data yang akurat, penelitian ini menggunakan sumber data primer dan sekunder. kemudian ditunjang dengan data yang dikumpulkan Melalui metode observasi, wawancara dan dokumentasi sebagaimana penelitian lapangan umumnya.

Dari hasil penelitian yang diperoleh melalui penelitian di lapangan dan ditunjang oleh kepustakaan disusun menjadi satu secara sistematis, maka dengan demikian sumber primer dan sumber skunder saling melengkapi sehingga diperoleh gambaran yang jelas mengenai mekanisme pengorganisasian dana ZIS yang dilakukan oleh BAZDA Kota Blitar terkait dengan keberadaan UU No. 38 tahun 1999 tentang Pengelolaan Zakat dan Keputusan Menteri Agama RI. Nomor 581 Tahun 1999 tentang Pelaksanaan UndangUndang Nomor 38 Tahun 1999 dan pola manajemen pengelolaan zakat, pelaksanaan dan pendayagunaan dana ZIS dan hambatan-hambatan serta uyapa yang dilakukan oleh BAZDA Kota Blitar.

\section{PEMBAHAASAN}

Sebagai sebuah lembaga, Badan Amil Zakat (BAZ) juga dikelola secara profesional dan didasarkan atas aturan-aturan keorganisasian. Pendekatan klasik terhadap manajemen dulunya dibangun pada gagasan bahwajikamanajemenmampumerencanakan, mengorganisasi, memimpin, dan mengendalikan pekerjaan dan organisasi dengan tepat, maka produktivitas akan meningkat. Pendekatan awal juga menekan aspek teknik pekerjaan, dengan mengorbankan aspek

\footnotetext{
122 Tim Dosen Fakultas Syari'ah, Buku Pedoman Penulisan Karya Ilmiah (Malang: Fakultas Syariah UIN, 2005), 11.

123 Creatad donsthekanto, Pengantar Penelitian Hukum (Jakarta: UI nanew'
} 
pribadi. Oleh karena itu, tidak mengherankan bahwa teori-teori yang dulu dikembangkan bertentangan dengan beberapa dasar manajemen terdahulu. ${ }^{124}$

Untuk terwujudnya suatu organisasi/lembaga yang baik maka perlu dirumuskan beberapa hal, yaitu; 1) Adanya tujuan yang akan dicapai, 2) Adanya penetapan dan pengelompokan pekerjaan, 3) Adanya wewenang dan tanggung jawab, 4) Adanya hubungan (relationship) satu sama lain, 5) Adanya penetapan orang-orang yang akan melakukan pekerjaan atau tugas-tugas yang diembankan kepadanya.

Undang-Undang RI Nomor 38 tahun 1999 tentang Pengelolaan Zakat Bab III pasal 6 dan pasal 7 menyatakan bahwa lembaga pengelola zakat di Indonesia terdiri dari dua macam, yaitu Badan Amil Zakat (BAZ) dan Lembaga Pengelolaan Zakat (LAZ), Badan Amil Zakat dibentuk oleh pemerintah, sedangkan Lembaga Amil Zakat didirikan oleh masyarakat. Dalam buku petunjuk teknis pengelolaan zakat yang dikeluarkan oleh Institusi Manajemen Zakat (2001) dikemukakan susunan organisasi lembaga zakat seperti Badan Amil Zakat. ${ }^{125}$

\section{Manajemen Zakat}

Pertama, Perencanaan Strategis Kelembagaan, Perencanaan dengan segala variasinya ditujukan untuk membantu mencapai tujuan suatu lembaga atau organisasi. Ini merupakan prinsip yang penting, karena fungsi perencanaan harus mendukung fungsi managemen berikutnya, yaitu fungsi pengorganisaian, fungsi pelaksanaan dan fungsi pengawasan. ${ }^{126}$

Pada dasarnya manajemen merupakan suatu rangkaian cara beraktivitas. Bagi seorang muslim manajemen bisa menjadi wahana amal kebajikan. Manajemen menumbuhkan kesadaran untuk mengaplikasikan cara-cara bekerja dengan landasan ajaran Islam. Manajemen islami memang tidak bebas nilai. Kaidah halal dan thayib menjadi nilai utama organisasi, hal ini berlaku dari awal pengambilan keputusan, perencanaan hingga aplikasi dan evaluasinya yang tetap melandaskan pada nilai-nilai halal dan thayib. ${ }^{127}$

Penekanan pada proses merupakan inti dari management by process (MBP). Pendekatan manajemen ini tidak mengutamakan hasil akhir. Dalam melaksanakan aktivitas, yang harus diperhatikan adalah

\footnotetext{
124 Gibson, Donnelly, Ivancecich, Manajemen Jilid 1 (Jakarta: Erlangga, 1997), 12.

125 Didin Hafidhuddin, Panduan Praktis Tentang Zakat Infaq Shadaqah (Jakarta: Gema Insani, 1998), 130

126 Sukarna, Dasar-Dasar Manajemen (Bandung: CV. Mandar Maju, 1992), 10.

127 Eri Sudewo, Manajemen Zakat (Ciputat: IMZ, 2004), 77.
}

upaya-upaya penghindaran kerugian pada pihak lain. Perkembangan yang sehat didorong. Antara satu dengan yang lain jadi saling mengisi, memperkuat berbagai sisi-sisi yang lemah. Tidak menimbulkan kerugian secara otomatis mengembangkan kemaslahatan.

Kedua, Perencanaan Tujuan Kelemba-gaan, merupakan suatu keniscayaan jika sebuah lembaga tidak mempunyai perencanaan tujuan kelembagaan. Badan/Lembaga Pengelolaan Zakat secara umum mempunyai visi dan misi sebagai berikut; 1) Menjadi pengelola zakat, infaq dan shadaqah yang amanah dan profesional, 2) Menjadi lembaga terdepan yang memiliki komitmen dalam mensejahterakan masyarakat melalui zakat, infaq dan shadaqah sesuai dengan ajaran Islam, 3) Menjadi lembaga sosial profesional yang didasari oleh syari'at Islam yang kukuh sebagai upaya mengembangkan kehidupan umat yang sejahtera, 4) Menjadi Baitul Mal yang representatif sebagaimana yang dilakukan oleh Rasulullah saw dan para sahabatnya.

Sedangkan secara operasional kelembagaan, misi khusus yang harus dilakukan oleh lembaga pengelola zakat adalah sebagai berikut; 1) Membina masyarakat yang kurang mampu menjadi masyarakat yang berkemampuan baik secara sosial maupun ekonomi agar memiliki komitmen dan keislaman melalui pengumpulan maupun penyaluran zakat. 2) Memberikan pelayanan kepada masyarakat yang kurang mampu (mustahiq) dalam pengembangan diri, dan atau keluarga menjadi masyarakat yang berkesejahteraan berdasarkan nilai agama Islam. 3) Memberikan contoh yang baik bagi masyarakat agar mau dan berkeinginann kuat untuk berzakat, infaq dan shadaqah demi kepentingan umum.

Dari visi dan misi akan dilahirkan programprogram unggulan sebagai implementasi pengelolaan zakat. Dari sejumlah program yang dicanangkan Badan/Lembaga Pengelola Zakat, dapat dikelompokkan menjadi empat program besar (grand programme), yaitu program ekonomi, program sosial, program pendidikan dan program dakwah. ${ }^{128}$

Ketiga,Perencanaan Sistem Penghitu-ngan Harta Zakat, Pembahasan zakat penghasilan memerlukan data tentang penerimaan dan pembiayaan. Sementara pembahasan tentang penerimaan memerlukan data harga dan produksi. Untuk rumah tangga muslim yang berhati-hati dalam bermuamalah untuk melaksanakan ketaatan beragama, masalah ini sangat penting karena berkaitan dengan kewajiban zakat bagi orang kaya 128 Departemen Agama, Pola Pembinaan Badan/Lembaga Amil Zakat
(Jakarta: Direktoratyenderal Bimbingan Masyarakat Islam \& Penyelengaraan
Haji Dir 
yang akan mengantarkan seorang muslim sukses di dunia dan juga sukses di akhirat. ${ }^{129}$

Setelah menentukan sumber dana/obyek harta wajib zakat, kemudian menentukan sistem dana/harta zakat. Tujuannya adalah agar masyarakat sendiri memahami betul pola penghitungan hartanya untuk menentukan apakah sudah sampai batas nishab atau ukuran wajib zakat atau belum. Selama ini sumber keengganan muzakki untuk mengeluarkan harta zakat dari hartanya, salah satunya adalah mereka tidak bisa menghitung hartanya sendiri sehingga mereka enggan atau tidak mau mengeluarkan zakatnya. ${ }^{130}$

Keempat, Pelaksanaan Dalam Penghimpunan Dana ZIS, Pengumpulan zakat dilakukan oleh Badan Amil Zakat dengan cara menerima atau mengambil dari muzakki atas dasar pemberitahuan muzakki. Badan Amil Zakat dapat kerja sama dengan Bank dalam pengumpulkan zakat harta muzakki yang berada di Bank atas permintaan muzakki. Badan Amil Zakat dapat menerima harta selain zakat, seperti, infaq, shadaqah. hibah, wasiat, waris dan kafarat.

Hal yang menggembirakan adalah kesadaran berzakat dikalangan kaum muslimin di Indonesia telah mengalami kemajuan. Ini dapat dilihat dengan munculnya lembaga-lembaga atau badan amil zakat, baik yang dikelola oleh pemerintah maupun swasta. Namun perkembangan yang menggembirakan ini belum menyentuh seluruh lapisan masyarakat kaum $\operatorname{muslimin}^{131}$.

Sebagaimana kita ketahui dan banyak dikeluhkan dikalangan pakar zakat, infaq dan shadaqah, bahwa dana ZIS tersebut belum secara optimal terealisasikan dan terjadi sebagaimana harapan kita sebagai kaum muslimin. Kalau kita perhatikan dari sekian banyak instansi pemerintah dan perusahaan di Indonesia, baru beberapa instansi pemerintah dan perusahaan yang mempunyai Unit Pengumpul Zakat (UPZ) yang telah dikelola dengan baik.

Berdasarkan beberapa pengalaman yang telah mereka hadapi saat awal-awal berdirinya juga mengalami berbagai macam konflik dalam rangka untuk memungut zakat di kalangan pegawai maupun masyarakat. Oleh karena itu diperlukan kiat-kiat atau strategi tertentu untuk menumbuhkan kesadaran berzakat di kalangan kaum muslimin.

Upaya untuk menumbuhkan kesadaran berzakat,

\footnotetext{
129 Sahri Muhammad, Mekanisme Zakat \& Permodalan Masyarakat Miskin (Malang: Bahtera Perss, 2006), 93.

$130 \quad$ Muhtadi Ridwan, Aplikasi Pengelolaan Dana ZIS Pada Lembaga Zakat, Infaq dan Shadaqah (Malang: Jurnal Ulul Albab UIN, 2002),. 34-35.

$131 \quad$ Nukthoh Arfawie Kurde, Memungut Zakat \& Infaq Profesi Oleh Pemerintah daerah (bagi pegawai negeri dan pegawai perusahaan daerah (Yogyakarta: Pustaka Pelajar, 2005), 38.
}

baik untuk pegawai institusional pemerintah maupun swasta, dapat dilakukan berbagai cara diantaranya adalah; 1) Memberikan wawasan (know how) yang benar dan memadai tentang zakat, infaq dan shadaqah, baik dari segi epistemologi, terminologi maupun kedudukannya dalam ajaran Islam, 2) Manfaat (benefit) serta hajat (need) dari zakat, infaq dan shadaqah, khususnya untuk pelakunya maupun para mustahiq zakat.

Karenanya untuk menumbuhkan kesadaran zakat di kalangan masyarakat, selain penting mengetahui tentang ketentuan fiqh mengenai wajibnya zakat, juga penting untuk memahami masalah zakat dalam kaitannya dengan faktor ajaran-ajaran Islam lainnya, seperti etika dan aqidah.

\section{Manajemen Pengolaan Dana ZIS di BAZDA Kota Blitar}

Organisasi Badan Amil Zakat Kota Blitar adalah organisasi masyarakat dalam rangka pengumpulan dan penyaluran zakat, infaq dan shadaqah. Ketua umumnya ialah seorang tokoh masyarakat yaitu $\mathrm{KH}$. Achfas Zen, seorang pengasuh pesantren putri di kelurahan Dauwan Kecamatan Kepanjen kidul kota Blitar, juga anggota DPRD Komisi D kota Blitar yang disegani umat serta memperoleh restu dan petunjuk dari pemerintah kota Blitar sebagai pengayonan amanah umat. Organisasi BAZDA kota Blitar berada diwilayah kantor Departemen Agama Kota Blitar dengan personalia terdiri dari unsur masyarakat, ulama' dan pemerintah. Tugas dari organisasi ini ialah merumuskan kebijakan mengenai pengumpulan dan penyaluran zakat, infaq dan shadaqah kepada yang berhak menerimanya sesuai dengan syari'at Islam.

Organisasi BAZDA kota Blitar, sebagaimana yang peneliti singgung di atas, yaitu tokoh masyarakat/ ulama' yang disegani dan dipercaya umat, serta mendapat restu dan petunjuk dari Pemerintah kota Blitar. Dalam tugasnya sehari-hari ketua BAZDA kota Blitar dibantu oleh Badan Pelaksana lainnya yang terdiri dari sekretaris dan wakil sekretaris (unsur pemerintah), bendahara dan wakil bendahara (unsur pemerintah) dan ketua unit-unit dan bendahara. Lembaga ini dibentuk secara vertikal sampai kepada instansi pemerintah kota Blitar, baik instansi pendidikan, industri, medis maupun profesi dan Bank dari tingkat pemerintah atas sampai pemerintah bawah.

Perencanaan merupakan fungsi utama dan pertama dari pada manajemen pada segala bidang dan tingkat manapun. Semakin tinggi kedudukan seseorang peentimpinpit organisasi, maka harus makin jauh

\section{(n) nitro $^{\text {PDF }^{\prime}}$ professional}


ke depan pandangannya, dalam hal perencanaan, tujuan pokok serta langkah-langkah jangka panjang atau garis besar usaha. Perencanaan dikembankan melalui latihan diri berfikir, secara sistematis dalam mengenali, kemudian merumuskan masalah-masalah yang dapat serta perlu dihadapi, dinilai, dianalisa kemudian memilih alternatif sebagai keputusan.

Maka Badan Amil Zakat daerah (BAZDA) Kota Blitar merumuskan langkah-langkah perencanaan dalam mengatur keuangan zakat, infaq dan shadaqah yang di peroleh dari masyarakat, pegawai dan instansi daerah kota Blitar, yaitu sebagai berikut; a) Merumuskan pendayagunaan dana zakat infaq dan shadaqah Mengumpulkan data dan informasi yang selengkap-lengkapnya untuk mengetahui langkah atas aktivitas apa yang pokok dan mana yang akan mempengaruhi pelaksanaan rencana itu. b) Pendataan para muzakki di seluruh wilayah kota Blitar, c) Terakhir adalah mengadakan persiapan untuk pengawasan pelaksanaannya.

Adapun sistem perhitungan dana zakat perspektif BAZDA Kota Blitar disesuaikan dengan hitungan syari'at yaitu 2,5\% dari penghasilan muzakki. Untuk itulah, sebelum melakukan penarikan zakat kepada muzakki, pengurus BAZDA Kota Blitar terlebih dahulu menjelaskan bagaimana pola penghitungan harta zakat.

\section{Hambatan dan Solusi}

Sebagaimana lembaga lainnya, dalam pengelolaan dana zis ini, BAZDA kota Blitar juga tidak terlepas dari hambatan-hambatan yang dirasakan baik yang bersifat internal maupun eksternal.

Secara internal, hambatan-hambatan yang dirasa cukup mengganggu kinerja organisasi atau lembaga ini adalah sebagai berikut:

Pertama, Terbatasnya fasilitas yang di-miliki oleh BAZDA Kota Blitar. Artinya, lembaga ini sampai sekarang belum memiliki kantor atau ruang kerja yang memadai dan representatif, sehingga mengganggu proses rekrutmen donatur sekaligus penyaluran dana ZIS.

kedua, Kurang memadainya SDM pengelola, lebih-lebih dilihat dari kualitas, tampaknya masih perlu ditingkatkan secara terus menerus. Sebab, dari sekian tenaga tersebut, tampaknya kurang memiliki kualitas keahlian sebagaimana yang dibutuhkan oleh BAZDA kota Blitar, seperti keahlian dalam bidang ekonomi atau ekonomi Islam.

Ketiga, Karena kurangnya SDM yang tersedia, lembaga ini juga belum maksimal dalam mengakses beberapa pihak yang diajak untuk kerja sama yang baik, di samping itu pula kurang koordinasi sehingga upaya untuk memaksimalkan organisasi sosial ini kurang efektif dalam pelaksanaan.

Keempat, Pengelola sendiri mempunyai pekerjaan ganda. Artinya di samping mengurusi Badan Amil Zakat, juga mempunyai tugas dan kewajiban lain yang lebih penting yaitu kebanyakan amil BAZDA kota Blitar bekerja disetiap instansi pemerintah kota Blitar (ikatan dinas).

Di samping hambatan internal di atas, dalam melaksanakan pengelolaan dana ZIS ini, juga tidak terlepas dari hambatan eksternal yaitu:

Pertama, Kurangnya kesadaran partisipasi masyarakat khusus karyawan/karyawati pemerintah kota Blitar terhadap upaya lembaga dalam pengelolaan dana ZIS. Hal ini terlihat dari hasil pengumpulan dana ZIS dari masing-masing UPZ di setiap instansi, semakin hari semakin berkurang. Dari jumlah UPZ 24 hingga akhir 2005 hanya terdapat 17 UPZ yang masih memberikan zakatnya, itupun tidak semua karyawan/karyawati yang ingin menginvestasikan zakatnya. Kurangnya partisipasi masyarakat khusus karyawan/karyawati ini disebabkan oleh antara lain; a) Kurang tersosialisasi konsep zakat, infaq dan shadaqah kepada masyarakat khususnya pemerintah daerah kota Blitar, b) Kurang tersosialisasikannya jenis-jenis harta wajib zakat, c) Kurangnya sosialisasi BAZDA kota Blitar sebagai lembaga amil zakat.

Kedua, Adanya muzakki potensial yang memaksakan kehendaknya untuk mendistribusikan ZISnya secara langsung kepada mustahiq. Artinya muzakki tersebut sudah mempunyai mustahiq sendiri.

Ketiga, Banyaknya lembaga-lembaga atau badan-badan pengelola zakat yang lain bermunculan sehingga membatasi ruang dan gerak BAZDA kota Blitar dalam menghimpun sekaligus dalam penyaluran dana.

Dari berbagai masalah yang dihadapi oleh BAZDA Kota Blitar, baik secara internal maupun eksternal, maka berikut beberapa upaya solusi yang ditawarkan dalam menghadapi persoalan-persoalan tersebut.

\section{Solusi Internal}

Pertama, Peningkatan SDM, Masalah sumber daya manusia dalam sebuah lembaga memang memiliki posisi yang terpenting. Untuk itulah setiap lembaga harus benar-benar memperhatikan persoalan ini seraca serius. Memahami begitu pentingnya peningkatáñ sưfmbet daya manusia Badan Amil Zakat 
Daerah kota Blitar akan mengadakan reorganisasi, berhubung masa kepengurusannya sudah habis ${ }^{132}$.

Kedua, Peningkatan Fasilitas Lembaga, Dengan adanya reorganisasi tersebut diharapkan bukan hanya sumber daya manusia saja yang harus dibenahi tapi lebih penting lagi adalah kebutuhan fasilitas lembaga, terutama kantor dan fasilitas lainnya. Walaupun selama ini kita sudah diberikan tempat oleh pemerintah kota, tapi belum kita gunakan dikarenakan sempit dan itupun hanya mempunyai satu ruang.

\section{Solusi Eskternal}

Pertama, Menginformasikan kepada masyarakat khususnya kepada pejabat teras pemerintah kota Blitar, bahwa pentingnya untuk menunaikan zakat untuk meringankan beban saudara-saudara kita yang kurang mampu, baik lewat surat edaran Walikota juga melalui pidato/khutbah jum'at.

Kedua, Bagi muzakki yang potensial yang mau mentasarrufkan sendiri zakatnya kepada mustahiq secara langsung kita memang berikan kesempatan, kalau memang itu yang terbaik baginya.

Ketiga, Masalah adanya lembaga lain dalam pengelola zakat, itu bukan masalah yang penting amanah dan bertanggung jawab dalam melaksanakan, terutama penyaluran zakatnya kepada yang membutuhkannya.

\section{Implementasi UU Nomor 38 Tahun 1999 di BAZDA Kota Blitar}

Dengan diterbitkannya Undang-Undang Republik Indonesia Nomor 38 tahun 1999 tentang Pengelolaan Zakat telah memberikan peluang besar kepada masyarakat untuk memaksimalkan potensi zakat umat yang mampu untuk mengeluarkan zakatnya guna untuk membantu saudara kita sesama muslim yang tidak mampu, dengan memberikan kepercayaan kepada badan/lembaga pengelola zakat baik daerah tingkat pusat, satu maupun daerah tingkat dua (kota dan kabupaten).

Pengelolaan zakat di Indonesia hingga kini belum memberikan hasil yang optimal. Pengumpulan maupun pemberdayaan Dana zakat masih belum mampu memberikan pengaruh terlalu besar bagi terwujudnya kesejahteraan umat Islam. Padahal pengelolaan zakat telah ditopang oleh sebuah perangkat hukum yaitu Undang Undang No. 38 tahun 1999 tentang Pengelolaan Zakat.

Lahirnya Badan Amil Zakat Daerah kota Blitar merupakan upaya untuk mengimplementasikan UU RI Nomor 38 tahun 1999 tentang Pengelolaan Zakat

\footnotetext{
132 Hasil wawancara dengan Ketua BAZDA kota Blitar (KH. Achfas Zen) tgl 1 Juni 2006
}

sebagaimana dalam pasal 6 ayat (1) dan (2) dikatakan bahwa pengelolaan zakat dilakukan oleh Badan Amil Zakat yang dibentuk oleh pemerintah, kemudian dalam ayat (2) dijelaskan bahwa pembentukan Badan Amil Zakat daerah kabupaten atau kota yang dibentuk oleh Bupati atau Wali Kota atas usul Kepala kantor Departemen Agama kabupaten atau kota.

Dengan mengacu kepada Undang Undang Zakat tersebut itulah pemerintah kota Blitar atas usulan Kantor Departemen Agama kota Blitar, Wali Kota Blitar mengeluarkan surat keputusan Nomor 27 tahun 2001 tentang Badan Amil Zakat, Infaq dan Shadaqah kota Blitar, yang terdiri dari Badan Pelaksana, Dewan Pertimbangandan Komisi Pengawas, yang mempunyai tugas dan tanggung jawab masing-masing, dengan harapan potensi zakat umat Islam kota Blitar dapat terorganisir dengan maksimal. Kendatipun demikian, upaya yang dilakukan oleh BAZDA kota Blitar akan memaksimalkan potensi Dana ZIS dengan harapan bahwa para mustahiq (kaum dhuafa') khususnya daerah kota Blitar dapat terangkat perekonomiannya. Maka BAZDA kota Blitar akan terus berusaha untuk mewujudkan visi dan misi itu.

Terkait dengan judul penelitian ini, tentunya apa yang diupayakan oleh pemerintah daerah kota Blitar untuk menjadikan BAZDA kota Blitar sesuai dengan Undang Undang Zakat, baik dalam upaya pengumpulan, pendayagunaan dan pendistribusian dana ZIS lebih profesional, karena dikelola oleh orang yang dianggap mampu dalam bidangnya. Memang secara konsep BAZDA kota Blitar didirikan atas lahirnya UU Nomor 38 tahun 1999 itu, akan tetapi upaya untuk mengimplementasikan pasal demi pasal dalam Undang Undang tersebut sangat nihil. Hal ini terbukti, dalam pasal 19 dikatakan bahwa Badan Amil Zakat memberikan laporan pelaksanaan tugasnya kepada Dewan Perwakilan Rakyat Republik Indonesia atau kepada Dewan Perwakilan Rakyat Daerah sesuai dengan tingkatannya, sampai saat ini BAZDA kota Blitar belum melaporkan hasil kerjanya kepada DPRD

Hal ini telah mencerminkan bahwa pengelola BAZDA kota Blitar belum maksimal, artinya belum ada usaha untuk benar-benar menerapkan konsep pengelolaan zakat dengan baik, sebagaimana yang telah termuat dalam Undang-Undang tersebut, apalagi bicara manajemen zakat yang itu membutuhkan sebuah perencanaan yang serius. Menurut G.R Terry dalam bukunya Sukarna "Dasar-Dasar Manajemen", dikatakan bahwa sebuah organisasi sosial harus ditopang oleh empat kekuatan pertama "Planning" (n) nitro $^{2}$ professional 
yang matang, kedua "Organizing”yang kuat, ketiga "Actuatyng" yang amanah dan "Controling" yang profesional. Keempat hal ini akan menjadi pilar-pilar penting dalam sebuah organisasi untuk mencapai tujuan.

BAZDA kota Blitar adalah sebuah organisasi sosial, semestinya membutuhkan upaya dan penangananyang serius dantekadyang bulatuntukmenjalankan tugas dan tanggung jawab yang diamanahkan kepada seluruh pengurus, baik badan pelaksana, dewan pertimbangan maupun komisi pengawas. Realitanya belum ada upaya untuk mengimplekasikan UndangUndang tersebut, apalagi harus melihat implikasi dari implementasi tersebut. Bukankah potensi kaum muslimin yang sadar untuk membayar, menginfakkan sedikit kelebihan harta muzakki akan bangga dan bahagia kalau mereka melihat Badan Amil Zakat mengelola dengan baik dana ZIS semata-mata untuk mengangkat derajat kaum dhuafa', bukan hanya dalam bentuk pendayagunaan secara konsumtif tradisional maupun kreatif, tapi lebih dari itu harus bersifat produktif keratif

Jusuf Kalla pernah mengatakan dalam sebuah pidato pembukaan Munas IV Asosiasi Organisasi Pengelola Zakat Indonesia. ${ }^{133}$ Menurut beliau para mengelola zakat di Indonesia untuk lebih berorientasi pada program kerja dari pada hanya sekedar mengedarkan formulir kepada para wajib zakat. "orang akan lebih banyak membayar zakat melihat adanya suatu kenyataan. Jadi harus menjadi program oriented, jangan formulir oriented.

Artinya orang akan lebih tertarik untuk membayar zakat apabila melihat ada program yang jelas yang ditawarkan oleh para pengelola zakat, maka akan semakin banyak muzakki untuk membayar zakatnya dan menginfakkan sebagian hartanya. Tapi kalau tidak ada program yang konkrit, para muzakki tidak akan pernah menerima formulir dari para $m u$ zakki. Jadi kita harus mengubah cara pandang dengan berorientasi kepada program yang nyata dan dapat dilihat serta dirasakan oleh masyarakat.

Pengelolaan zakat di Indonesia hingga kini belum memberikan hasil yang optimal apalagi skala lokal. Pengumpulan maupun pemberdayaan Dana zakat masih belum mampu memberikan pengarus terlalu besar bagi terwujudnya kesejahteraan umat Islam. Padahal, pengelolaan zakat telah ditopang oleh sebuah perangkat hukum yaitu UU Nomor 17 tahun 1950, UU Nomor 22 tahun 1999, UU Nomor 38 ta- hun 1999, Keputusan Presiden RI Nomor 8 tahun 2001, Keputusan Bersama Menteri Dalam Negeri dan Menteri Agama Nomor 29 tahun 1999 dan nomor 17 tahun 1999 dan Intruksi Menteri Agama Nomor 7 tahun 1998.

Menurut Ketua Umum Forum Zakat (FOZ), Naharus Surur, ${ }^{134}$ kurang optimalnya keberadaan UU ini disebabkan paling tidak oleh dua hal, yaitu sosialisasi dan perangkat pelaksana UU itu sendiri. Pemerintah memang mestinya memiliki andil besar dalam kedua hal tersebut. Ia mencontohkan langkah sosialisasi. Memang benar apa yang dikatakan oleh Ariyanto ${ }^{135}$, bahwa pemerintah itu sebagaimana dalam Panca Pra Setia Korpri, dikatakan bahwa Pemerintah/PNS harus menjadi contoh masyarakat. Pemerintah belum bisa berbuat banyak sehingga masyarakat pun belum memiliki pemahaman yang baik mengenai zakat. Tak heran jika kemudian masyarakat, yang juga salah satu faktor penentu bagi optimalnya pengelola zakat yang harus mereka tunaikan. Sementara Tulus, ${ }^{136}$ menyatakan, dalam rangka optimalisasi zakat di Indonesia mestinya memang melaksanakan UU Nomor 38 tahun 1999 secara konsekuen. Artinya apa yang diamarkan dalam Undang Undang tersebut dapat dilaksanakan dengan baik.

Semestinya pemerintah kota Blitar, sebagaimana yang peneliti singgung di atas, harus memiliki peran yang besar dalam pengelolaan zakat. Misalnya pemerintah memberikan fasilitas dan bantuan dalam penggalangan dana ZIS. Namun dalam kenyataannya langkah ini belum berjalan secara optimal, baik pemberian sarana, pembinaan SDM maupun bantuan dana operasional, tapi saat ini kata Ariyanto bahwa "pemerintah kota Blitar belum memahami dan mengerti tentang wajib zakat sebagaimana wajibnya shalat".

Sebenarnya, sebagaimana hasil wawancara dengan pengurus BAZDA kota Blitar, bahwa upaya untuk mensosialisasikan kepada muzakki yang ada di instansi/badan/dinas pemerintah kota Blitar sudah dilaksanakan, baik melalui kerja sama dengan pihak instansi secara door to door, maupun dengan cara mengumpulkan seluruh karyawan/karyawati untuk wajib zakat dengan memotong gaji pegawai 2,5\%. Di samping itu juga pengurus BAZDA kota Blitar mensosialisasikan lewat khutbah-khutbah. Tapi hasilnya tetap nihil.

Upaya untuk menumbuhkan kesadaran berzakat,

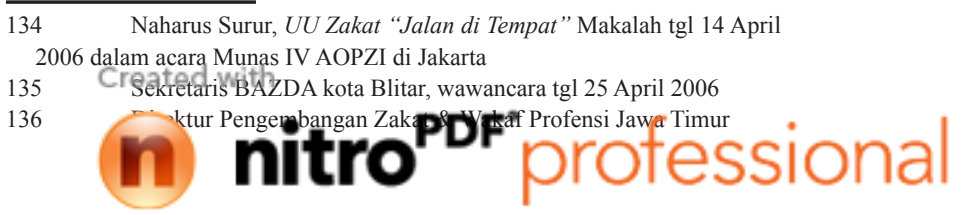


baik untuk pegawai institusional pemerintah maupun swasta, tidak cukup hanya dengan lisan, surat maupun lewat khutbah dan ceramah keagamaan, tapi juga dapat dilakukan berbagai cara di antaranya adalah:

Pertama, Memberikan wawasan (know how) yang benar dan memadai tentang zakat, infaq dan shadaqah, baik dari segi epistemologi, terminologi maupun kedudukannya dalam ajaran Islam.

Kedua, Manfaat (benefit) serta hajat (need) dari zakat, infaq dan shadaqah, khususnya untuk pelakunya maupun para mustahiq zakat. Karenanya untuk menumbuhkan kesadaran zakat di kalangan masyarakat, selain penting mengetahui tentang ketentuan fiqh mengenai wajibnya zakat, juga penting untuk memahami masalah zakat dalam kaitannya dengan faktor ajaran-ajaran Islam lainnya, seperti etika dan aqidah.

Kalau kita melihat secara sepintas, memang menjadi polemik di kalangan masyarakat kota, dengan diwajibkan zakat, terutama zakat profesi di pemerintah kota Blitar, karena Undang Undang Zakat berbeda dengan Undang Undang Pajak, yang mengatur setiap warga untuk membayar pajak dan sifatnya imperatif, kalau Undang Undang Zakat hanya mengatur bagaimana cara pengelolaan zakat yang profesional. UU No. 38 tahun 1999 tentang Pengelolaan Zakat dan Keputusan Direktur Jenderal Bimbingan Masyarakat Islam dan Urusan Haji Nomor D /291 tahun 2000 tentang Pedoman Teknis Pengelolaan Zakat. Meskipun harus diakui bahwa dalam peraturan-peraturan tersebut masih banyak kekurangan yang sangat mendasar, misalnya tidak dijatuhkannya sanksi bagi muzakki yang melalaikan kewajibannya (tidak mau berzakat), tetapi undangundang tersebut mendorong upaya pembentukan lembaga pengelolaan zakat yang amanah, kuat dan dipercaya oleh masyarakat.

Sebenarnya bukan masalah adanya aturan atau undang-undang sehingga kita harus membayar, karena zakat itu sendiri adalah ibadah ijtima'iyah yang mempunyai peran tersendiri dalam syari'at Islam. Jadi perlu adanya kesadaran dari kaum muslimin untuk membantu kaum papa/dhuafa'. Lebih dari itu juga perlu adanya pengelolaan yang profesional dari amil itu sendiri, sehingga mempunyai arah yang jelas, tepat guna dan bermanfaat buat fakir miskin.

BAZDA kota Blitar, dengan mengacu kepada UU No. 38 tahun 1999 tersebut sudah berupaya untuk mengelola zakat secara professional, tapi tidak semua apa yang kita rencanakan akan berjalan dengan maksimal, artinya implikasi dari implementasi UU itu sangat nihil sekali. Sebenarnya setelah dilakukan pengamatan secara langsung oleh peneliti akhirnya BAZDA kota Blitar belum mempunyai perencanaan yang konkrit, sehingga dengan tidak adanya perencanaan itulah pengurus BAZDA kota Blitar tidak mengerti apa yang seharusnya dilakukan dengan harta ZIS yang setiap tahun bahkan setiap bulan ada memasukan dari beberapa pihak atau instansi pemerintah.

\section{KESIMPULAN DAN SARAN}

\section{Kesimpulan}

Berdasarkan hasil penelitian tentang Implementasi UU Nomor 38 tahun 1999 tentang Pengelolaan Zakat di BAZDA kota Blitar, maka dapatlah peneliti mengambil kesimpulan sebagai berikut: Pertama, Badan Amil Zakat Daerah (BAZDA) kota Blitar, secara historis terbentuknya atas usulan dari kantor Departemen Agama kota Blitar dan perundang-undangan yang ada, terutama UU Nomor 38 tahun 1999 tentang Pengelolaan Zakat, walaupun demikian hasil survey dan riset, bahwa secara konseptual BAZDA kota Blitar memang tidak terlepas dari Undang Undang tersebut, tapi secara praktis belum bisa mencerminkan keberadaan UU Nomor 38 tahun 1999 tentang Pengelolaan Zakat, Kedua, Manajemen dalam organisasi sangat dibutuhkan, sebagai upaya untuk mencapai tujuan dari organisasi tersebut. Tidak terlepas dari Badan/Lembaga Pengelola Zakat itu sendiri. Untuk mencapai tujuan yang diharapkan perlu adanya manajemen yang baik dalam pengelolaan, pengumpulan, pendayagunaan dan pendistribusian Dana Zakat, Infaq dan Shadaqah, sehingga tepat sasaran, tepat guna dan bermanfaat bagi para mustahiq, bukan hanya dalam jangka pendek, tapi lebih dari itu, jangka pajang. Manajemen yang dimaksud adalah 1) Perencanaan, 2) Organisasi 3) Pelaksanaan dan 4) Pengawasan. Lain halnya dengan BAZDA kota Blitar, sebagai organisasi sosial, manajemen yang peneliti ungkapkan diatas sangat penting untuk diterapkan. Kecendrungan itu kearah sana masih belum terwujud dikarenakan beberapa hambatan, baik secara internal maupun eksternal.

\section{Saran}

Untuk meningkatkan sistem pengelolaan dan manajemen zakat dengan baik peneliti memberikan saran-saran, baik kepada Pemerintah Kota Blitar maupun kepada Pengurus BAZDA Kota Blitar :

Pemerintah Kota Blitar; Pertama, Hendaknya pemerintahekotat Blitar (walikota) melakukan pembinaan low intensif terhadap berbaga pengelola za(n) nitro professional 
kat baik yang berbentuk Badan Amil Zakat (BAZ) maupun Lembaga Amil Zakat (LAZ) di lingkungan kota Blitar; Kedua, Untuk mengoptimalkan cara kerja BAZDA kota Blitar, hendaknya pemerintah kota Blitar (walikota) memberikan kantor yang permanen dan alat penunjang kantor seperi komputer dan lain-lain; Ketiga, Mengaktifkan kembali UPZ-UPZ disetiap Instansi/Badan/Dinas pemerintah kota Blitar, tanpa terkecuali; Keempat, Pembentukan pengurus baru (reorganisasi) harus mengutamakan SDM, sehingga pengelolaan, pemungutan dan pendayagunaan Dana ZIS bisa maksimal, Kelima, Harus ada pengawasan yang intensif dari pemerintah kota Blitar

Pengurus BAZDA Kota Blitar, Pertama, Lebih berorientasi pada program oriented, bukan formulir oriented, Kedua, Perlu membangun hubungan kerja yang sinergis dengan lembaga lain yang sejenis, untuk meningkatkan kemitraan dan menyiaran ajaran Islam, khususnya tentang ZIS, Ketiga, Untuk memanej pengelolaan zakat lebih baik lagi, sebagaimana manajemen organisasi lain, yaitu harus ada Planning, Organizing, Actuatyng dan Controling, Sehingga bisa lebih profesional, Keempat, Sosialisasi tentang keberadaan BAZDA kota Blitar dan programprogramnya harus dilakukan dan terus menerus, termasuk masyarakat kota, baik pemerintah, non pemerintah, perguruan tinggi dan lain-lain.

\section{DAFTAR PUSTAKA}

Departemen Agama 1971, al-Qur'an dan Terjemehannya, Jakarta: Yayasan Penyelenggara Penterjemahan/I'enefsiran Al-Qur'an. , (2005), Pola Pembinaan Badan/ Lembaga Amil Zakat (Jakarta: Direktorat Jenderal Bimbingan Masyarakat Islam \& Penyelengaraan Haji Direktorat Pengembangan Zakat dan Wakaf.

Gibson, Donnelly, Ivancecich, (1997), Manajemen Jilid 1, Jakarta: Erlangga.

Hafidhuddin, Didin, (1998) Panduan Praktis Tentang Zakat Infaq Shadaqah. Jakarta: Gema Insani.

Ja'far, Muhammadiyah, (1985), Zakat, Puasa dan Haji. Malang: Kalam Mulia.

Kurde, Nukthoh Arfawie, (2005) Memungut Zakat \& Infaq Profesi Oleh Pemerintah Daerah (Bagi Pegawai Negeri dan Pegawai Perusahaan Daerah). Yogyakarta: Pustaka Pelajar.

Muhammad, Sahri (2006) Mekanisme Zakat Permodalan Masyarakat Miskin, Malang:
Bahtera ferss.

Ridwan, Muhtadi, (2002) Aplikasi Pengelolaan Dana ZIS Pada Lembaga Zakat, Infaq dan Shadaqah, Malang: Jurnal Ulul Albab UIN.

Soekanto, Soerjono, (1986) Pengantar Penelitian Hukum, Jakaria: UI Press.

Sudewa, Eri. (2004) Munajemen Zakat, Jakarta: Institut Manajemen Zakat

Sukarna, (1992) Dasar Dasar Manajemen, Bandung: CV. Mandar Maju.

Tim Dosen Fakultas Syari'ah, (2005) Buku Pedoman Penulisan Ilmiah, Malang: Fakultas Syariah UIN. 